\title{
A review of polioencephalomalacia in ruminants: is the development of malacic lesions associated with excess sulfur intake independent of thiamine deficiency?
}

\author{
Samat Amat ${ }^{1 *}$, Andrew A. Olkowski ${ }^{2}$, Metin Atila ${ }^{3}$ and Tyler J. O'Neill ${ }^{4}$ \\ *Correspondence: saa647@mail.usask.ca \\ 'Department of Veterinary Pathology, Western College of Veterinary Medicine, University of Saskatchewan, Saskatoon, \\ SK S7N 5B4, Canada. \\ 2Department of Animal and Poultry Science, College of Agriculture and Bioresources, University of Saskatchewan, Saskatoon, \\ SK S7N 5A8, Canada. \\ ${ }^{3}$ Department of Biochemistry, College of Medicine, University of Saskatchewan, Saskatoon, SK S7N 5E5, Canada. \\ ${ }^{4}$ Dalla Lana Faculty of Public Health, Division of Epidemiology, University of Toronto, Toronto, ON M5T 3M7, Canada.
}

\begin{abstract}
Polioencephalomalacia (PEM), also known as cerebrocortical necrosis, is an important neurologic disease that affects ruminants. Thiamine deficiency and sulfur (S) toxicity have been well recognized as major etiological factors. The mechanism of thiamine deficiency associated PEM has been well elucidated. However, the role of S in PEM pathogenesis remains unclear, although the relationship between S toxicity and PEM has been established for 3 decades. The development of S-induced malacic lesions is believed to be independent of thiamine deficiency, since blood thiamine levels in affected individuals remain in the range of normal animals. However, cattle affected by S-induced PEM frequently respond to thiamine treatment in early disease stages. Thiamine supplementation is reported to reduce the incidence and severity of S-induced PEM. This suggests a possible metabolic relationship between excess S intake and thiamine in the development of malacic lesions. Such an association is further supported by recent studies reporting that high dietary $S$ may increase the metabolic demand for thiamine pyrophosphate (TPP), a critical cofactor in several metabolic pathways. Systemic failure to synthesize metabolically requisite levels of TPP in the brain may be an important precursor in the pathogenesis of S-induced PEM. There is increasing evidence of the importance of thiamine in the pathogenesis of S-induced PEM. Thus, understanding the potential role of S-thiamine interaction in the development of malacic lesions is important step to determine the mechanism of S-induced PEM. The objective of this article is to provide an overview of thiamine deficiency and S toxicity associated PEM, and to discuss the potential role of S-thiamine interaction in the pathogenesis of S-induced PEM in ruminants.
\end{abstract}

Keywords: Polioencephalomalacia, sulfur, thiamine, interaction, malacic lesions, ruminants

\section{Introduction}

Polioencephalomalacia (PEM), softening of grey matter, is an important neurological disease process that can affect many species of ruminants and contributes to substantial economic loss to livestock industry [1]. This disease is characterized by necrosis of the cerebral cortex [2]. Animals of all ages can be affected but young animals appear to be more vulnerable $[3,4]$. Several risk factors such as thiamine deficiency, S toxicity, lead toxicity, and water deprivation-sodium ion toxicity have been implicated in the development of PEM. All these factors produce similar brain lesions $[3,5]$. Regardless of the suspected cause of PEM, affected animals frequently respond to thiamine administration [6-8]. For this reason, it is commonly believed that thiamine deficiency is a major metabolic factor involved in the pathogenesis of PEM. However, the biochemical mechanisms of lesion development are not known.

It has been suggested that the inhalation and absorption of eructated hydrogen sulfide $\left(\mathrm{H}_{2} \mathrm{~S}\right)$ gas generated from the rumen is the major risk factor leading to S-induced PEM [5]. To date, however, there is no convincing evidence to support the theory that the concentration of inhaled $\mathrm{H}_{2} \mathrm{~S}$ from the rumen is high enough to induce PEM lesions. Furthermore, cattle affected by S-induced PEM frequently respond to thiamine treatment [9-11], and thiamine supplementation decreased the incidence and severity of S-induced PEM [12]. In this context, it is difficult to reconcile possible direct association between inhaled $\mathrm{H}_{2} \mathrm{~S}$ and thiamine deficiency that may explain pathogenesis of necrotic lesions in the cerebral cortex.

Sulfite, a toxic intermediary metabolite of $S$ in ruminants, may play key role in the development of PEM lesions [7]. The sulfite ion is a strong nucleophile and has the capacity to destroy thiamine [13]. Thus, thiamine deficiency appears to be a plausible risk factor involved in the etiology of PEM associated with excessive intake of $\mathrm{S}$. A recent study by Amat et al., [11] reported reduced thiamine pyrophosphate (TPP), an active form of thiamine involved as a co-factor in several key 
Amat et al. Veterinary Medicine and Animal Sciences 2013,

metabolic pathways, in the brains of S-induced PEM affected cattle, suggesting a more complex metabolic relationship between $\mathrm{S}$ and thiamine in the development of malacic lesions than previously postulated. The objective of this article is to provide an overview of thiamine deficiency and $S$ toxicity associated PEM, and to discuss the potential role of S-thiamine interaction in the pathogenesis of S-induced PEM in ruminants.

\section{Review}

\section{Thiamine deficiency induced PEM}

Thiamine deficiency induced PEM has been reported in cattle, sheep, horses, dogs [6], goats [14], camels [15], and cats [16]. Thiamine deficiency in ruminants has be associated with several factors such as an impairment of microbial thiamine synthesis, thiamine destroying activity of bacterial thiaminase, along with other dietary factors involved in thiamine destroying activity in the rumen [17]. Bacterial thiaminase has been considered the main factor leading to thiamine deficiency in ruminants. Two types of thiaminase (Type I and II) are produced by different types of ruminant bacteria [18]. Both types have a destructive effect on thiamine in the rumen. Thiaminase type I catalyzes the nucleophilic displacement of the thiazole moiety of thiamine by another base known as a co-substrate and generates thiamine analogues that inhibit thiamine dependent reactions. Thiaminase type I requires a co-factor to accomplish its thiamine destroying activity [18]. Some medications such as promazines and levamisole along with substrates produced during fermentation appear to be act as cofactor to thiaminase type I [18]. Thiaminase type I is also present in plants such as bracken fern, horsetail and nar do ferns [4]. Animals exposed to these plants have subsequently developed PEM $[19,20]$. Thiaminase type II splits thiamine by catalyzing the hydrolysis process and thereby may reduce the amount of thiamine absorbed from rumen [21]. Several outbreaks of PEM in sheep and cattle with high thiaminase activity in the rumen have been reported $[2,22]$.

Amprolium, a potent coccidiostat and thiamine analogue, is believed to be another major factor associated with PEM. It inhibits the conversion of free-base thiamine to TPP, thereby depriving tissues (especially brain) of TPP $[\mathbf{1 8}, \mathbf{2 3}]$. Thornber et al., [24] induced PEM in lambs by feeding a thiamine free diet with high levels of amprolium ( $280 \mathrm{mg} / \mathrm{kg}$ of BW). As well, oral administration of amprolium leads to a reduction of blood and tissue thiamine levels and subsequent development of PEM in calves [25]. However, clinical and histopathological lesions indicative of thiamine deficiency have been produced in pre-ruminant lambs by feeding a thiamine free artificial milk diet [26]. These researchers questioned the hypothesis that the amprolium could be the major factor causing PEM.

Other factors, such as production of inactive or poorly absorbed forms of thiamine in the rumen, or inhibition of phosphorylation and absorption may also contribute to functional thiamine deficiency (TPP deficiency), subsequently leading to malacic lesions [18].

\section{Sulfur-induced PEM}

Sulfur toxicity has become increasingly accepted as a major cause of PEM and there are numerous reports regarding dietary $S$ levels arranging from $0.45 \%$ to $0.6 \%$ on dry matter (DM) basis that caused clinical and experimental PEM [27-32]. The hypothesis regarding high dietary $\mathrm{S}$ associated PEM was first proposed by Raisbeck in 1982 [33] and was further supported by Gooneratne et al., [36] and Gould et al., [35]. Gooneratne et al., [36] experimentally developed PEM in sheep by feeding a diet containing $0.63 \% \mathrm{~S}$, a value $0.23 \%$ higher than the recommended maximum tolerable level (0.4 \% DM basis) in cattle diet to prevent PEM (NRC 1986) [37]. Gould et al., [35] also induced PEM in Holstein steers by feeding an experimental diet with added sodium sulfate $\left(\mathrm{NaSO}_{4}\right)$. Case reports of S-induced PEM have been reported feedlots globally $[1,11,38-40]$.

\section{Proposed mechanisms of sulfur-induced PEM}

Although S-induced PEM has been recognized in the last 3 decades, the role that S plays in PEM remains unclear [7]. It has been suggested that lesion development is associated with the inhalation of eructated $\mathrm{H}_{2} \mathrm{~S}$ from the rumen [5]. When excess $S$ is ingested, a relatively high concentration of sulfide is being generated as a result of $S$ reduction by rumen microbes. Some sulfide from the fluid phase is released into the rumen gas cap as $\mathrm{H}_{2} \mathrm{~S}$ (Figure 1). Formation of $\mathrm{H}_{2} \mathrm{~S}$ from the sulfide ion is $\mathrm{pH}$ dependent. As rumen $\mathrm{pH}$ drops, the $\mathrm{H}_{2} \mathrm{~S}$ in the rumen gas cap increases [5]. Since ruminants inhale $70-80 \%$ of the eructed gas [41], it is proposed that most of the eructed $\mathrm{H}_{2} \mathrm{~S}$ gas may be absorbed into the pulmonary blood system via inhalation of eructed gas, and some inhaled $\mathrm{H}_{2} \mathrm{~S}$ may reach the brain without undergoing hepatic detoxification leading to toxic damage [5].

Sulfide in the brain tissue is converted into sulfate via the mitochondrial sulfide oxidation process [42]. Tissues that have a high oxygen demand, such as brain, are more sensitive to disruption of oxidative metabolism by sulfide [43], the primary mechanism for sulfide toxicity. Sulfide oxidation is linked to the respiratory electron transport chain, at the level of cytochrome c. Mitochondrial sulfide oxidation is inhibited by high sulfide concentrations [44]. When sulfide concentration exceeds a certain level, cytochrome c oxidase, the last enzyme in the respiratory electron transport chain of mitochondria, is inhibited. As a result, ATP production through oxidative phosphorylation is blocked [45].

Monitoring levels of ruminal $\mathrm{H}_{2} \mathrm{~S}$ gas has been proposed as means of screening animals at potential risk of S-induced PEM. Gould [46] suggested that rumen gas $\mathrm{cap}_{2} \mathrm{~S}$ concentrations greater than $1000 \mathrm{ppm}$ are potentially toxic and over $2000 \mathrm{ppm}$ can precede the development of PEM. Sulfur-induced PEM affected ruminants have shown a variety $\mathrm{H}_{2} \mathrm{~S}$ concentration ranging from less than 200 ppm (Amat et al., unpublished 


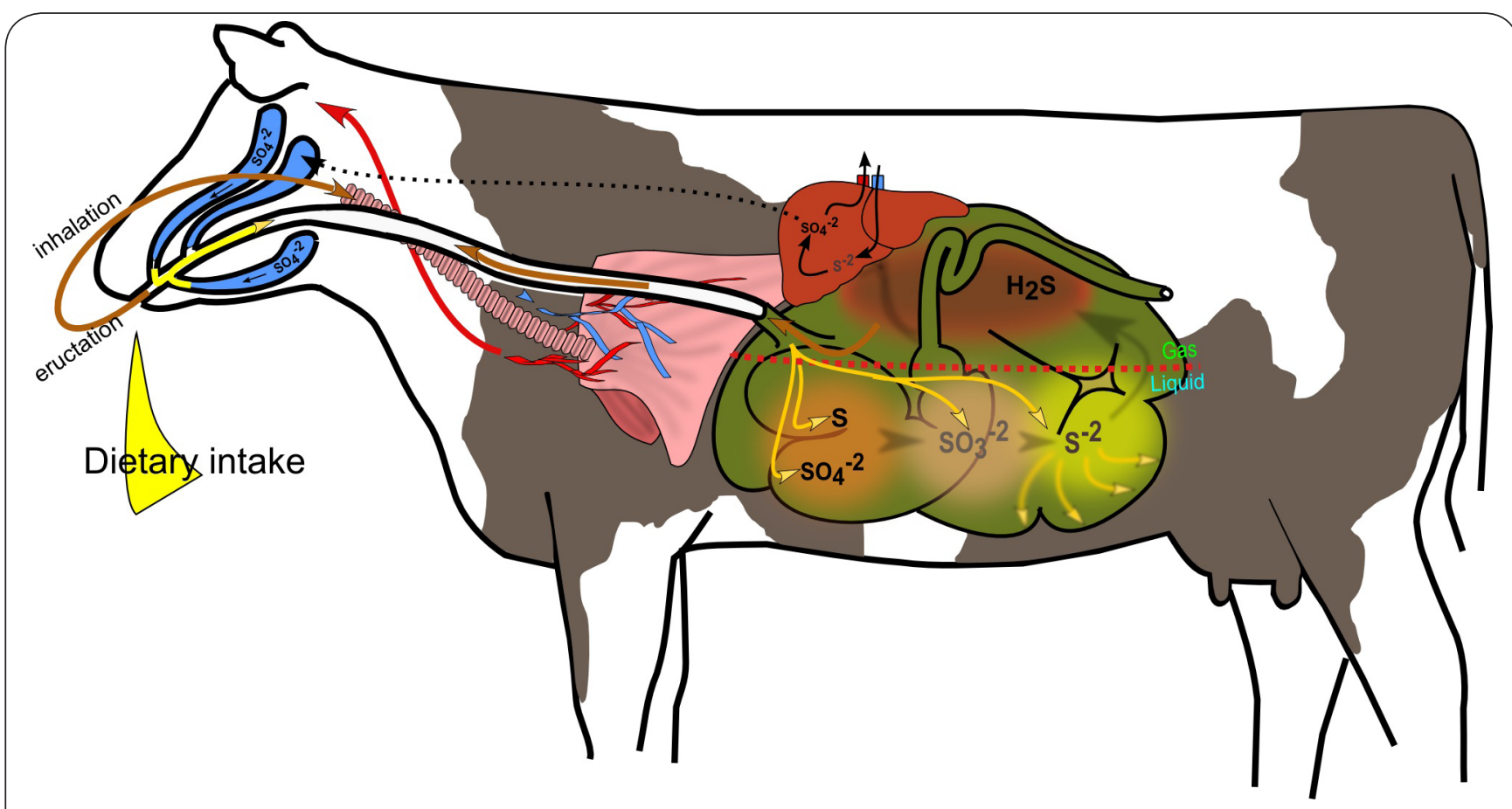

Figure 1. Schematic of sulfur metabolism in ruminants. Dietary sulfur containing molecules are represented in yellow. Accumulation of $\mathrm{H}_{2} \mathrm{~S}$ in gas phase of the rumen, its eructation and inhalation are indicated with brown color. Sulfide contaminated blood flow to the brain is represented by red arrow. Sulfate recycling back to the rumen with saliva is represented by black dash line with arrow. $\mathrm{S}$, elemental sulfur; $\mathrm{SO}_{3}{ }^{-2}$, sulfite; $\mathrm{SO}_{4}^{-2}$, sulfate; $\mathrm{H}_{2} \mathrm{~S}$, hydrogen sulfide.

observation) up to $25000 \mathrm{ppm}$ [47]. Neville et al., [48] reported that ruminants exposed to elevated dietary S $(0.65 \%$ or $0.83 \%$ DM) exhibited relatively high $\mathrm{H}_{2} \mathrm{~S}$ gas ranging from 2000 to 8000 ppm, but did not show clinical signs of PEM. Similarly, Amat et al., [11] did not observe any clinical or histopathological changes associated with PEM in beef heifers fed high dietary $\mathrm{S}(0.62 \% \mathrm{~S}, \mathrm{DM})$, despite the elevated ruminal $\mathrm{H}_{2} \mathrm{~S}$ level $(2296$ $\mathrm{ppm})$. However, it has been reported that cattle with clinical signs of PEM have lower ruminal $\mathrm{H}_{2} \mathrm{~S}$ than those clinically normal steers $\left(\mathrm{H}_{2} \mathrm{~S}>2000 \mathrm{ppm}\right)$ [46]. Loneragan et al., [40] also reported that lower ruminal $\mathrm{H}_{2} \mathrm{~S}(450 \mathrm{ppm})$ in clinically PEM affected calves. Contributing to the complexity of the condition, Richter et al., [47] reported that a yearlings steer that developed clinical signs of PEM and died due to high dietary S intake $(0.5 \% \mathrm{~S}, \mathrm{DM})$ had $1000 \mathrm{ppm}$ ruminal concentrations of $\mathrm{H}_{2} \mathrm{~S}$. It has also been observed that animals with S-induced PEM show clinical signs with ruminal $\mathrm{H}_{2} \mathrm{~S}$ concentrations $\leq$ $400 \mathrm{ppm}$, whereas ruminal $\mathrm{H}_{2} \mathrm{~S}$ in clinically normal cattle was 2000-3600 ppm (Amat et al., unpublished observation). Taken together, $\mathrm{H}_{2} \mathrm{~S}$ may not be a reliable clinical chemistry indicator for assessing the risk of PEM.

Incidence of PEM in cattle has been associated with direct inhalation of $\mathrm{H}_{2} \mathrm{~S}$ from the poison gas wells and manure slurry pits [49]. However, there is no conclusive evidence to support the theory that the concentration of inhaled $\mathrm{H}_{2} \mathrm{~S}$ from the rumen is high enough to induce PEM lesions in the brain of ruminants. Olkowski [7] argued that the concentration of $\mathrm{H}_{2} \mathrm{~S}$ generated in the rumen of animals exposed to moderate $\mathrm{S}$ may not be sufficient to exert acute toxic effects to the brain. In addition, inhalation of eructed $\mathrm{H}_{2} \mathrm{~S}$ is reported to cause lung tissue damage $[41,46]$. However, Niles et al., [50] did not observe any clinical or gross post-mortem signs of lung damage in calves exposed to high dietary $S$ and had ruminal $\mathrm{H}_{2} \mathrm{~S}$ concentrations reaching $24,000 \mathrm{ppm}$. Furthermore, they performed a breath analysis of expired air on calves in the same study and measured $\mathrm{H}_{2} \mathrm{~S}$ and fond no detectable amount of $\mathrm{H}_{2} \mathrm{~S}$ from the expired air of the calves. It is questionable whether inhalation of $\mathrm{H}_{2} \mathrm{~S}$ generated in the rumen is the direct causal factor in the pathogenesis of S-induced PEM.

When the physiological and pathophysiological functions of $\mathrm{H}_{2} \mathrm{~S}$ in the brain are considered, it seems to be unlikely that inhalation of eructed ruminal $\mathrm{H}_{2} \mathrm{~S}$ can reach an over-dose threshold in ruminants exposed to low to moderate levels of excess dietary $\mathrm{S}$. The toxicity of $\mathrm{H}_{2} \mathrm{~S}$ to the nervous system may only occur under the condition of over-dose of exogenous $\mathrm{H}_{2} \mathrm{~S}$ (personal communication with Dr. H. Kimura, 2011). Hydrogen sulfide is endogenously produced by some enzymes in the mammalian tissues [51] and acts as neuromodulator/ transmitter, and neuro-protector in the brain [51-54]. It plays an important role in protecting neurons from oxidative stress by scavenging free radicals and reactive species, recovering glutathione levels, inhibiting intracellular $\mathrm{Ca}^{2+}$ status $[51,55]$ 


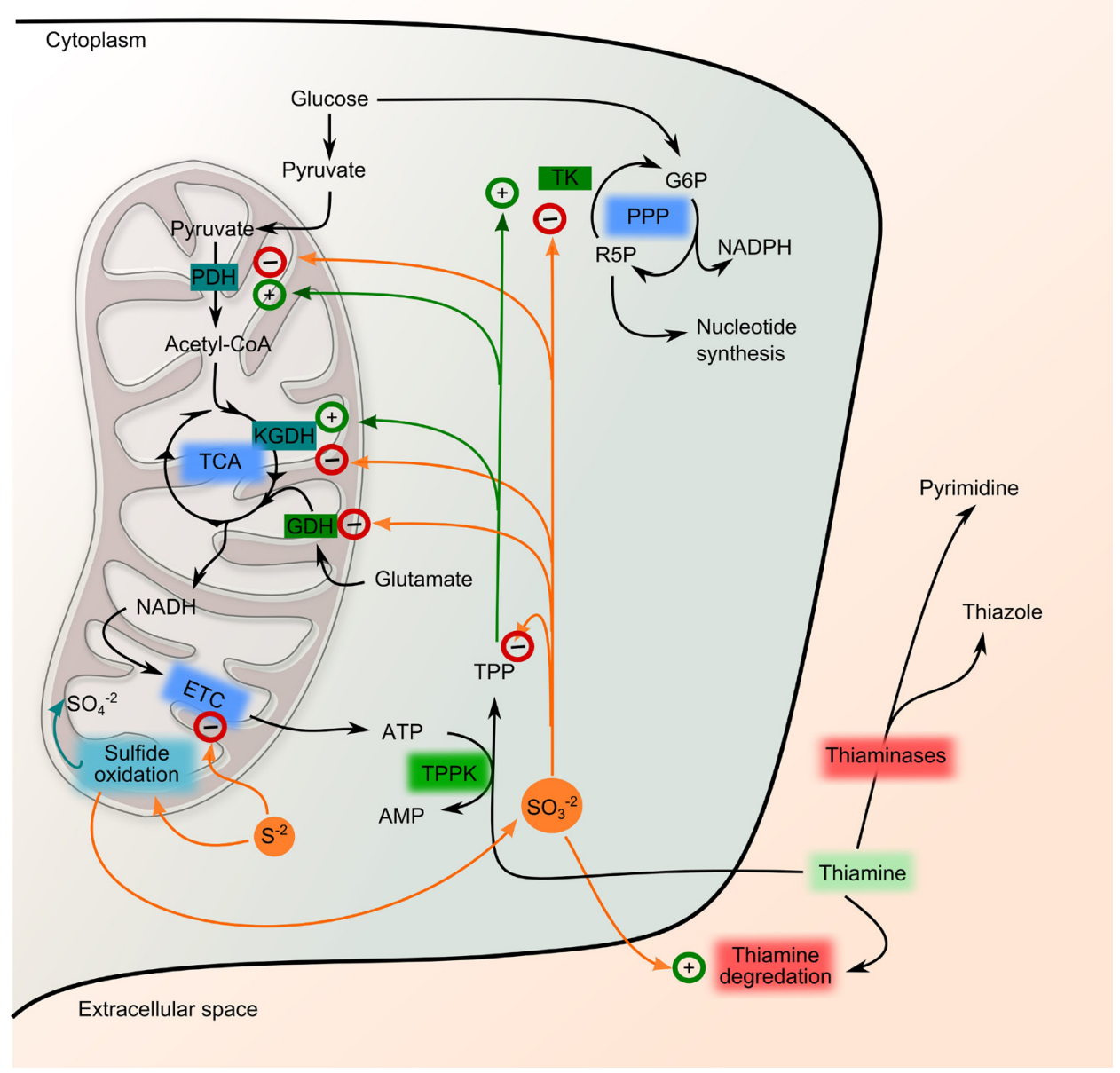

Figure 2. Schematic of thiamine and sulfite effect in some cellular activities. (AMP, adenosine monophosphate ATP, adenosine triphosphate; ETC, electron transport chain; GDH, glutamate dehydrogenase; G6P, glucose 6-phosphate; KGDH; a-ketagluterate dehydrogenase; NADH, nicotinamide adenine dinucleotide; NADPH, nicotinamide adenine dinucleotide phosphate; $\mathrm{PDH}$, pyruvate dehydrogenase; PPP, pentose phosphate pathway; R5P, ribose 5-phosphate; $\mathrm{S}^{2-}$, sulfide; $\mathrm{SO}_{3}^{-2}$, sulfite; $\mathrm{SO}_{4}^{-2}$, sulfate; TCA, citric acid cycle; TK, transketolase; TPPK, thiamine pyrophosphokinase; TPP, thiamine pyruphosphate).

Hydrogen sulfide is also reported to reduce the generation of reactive oxygen species (ROS) from mitochondria by inhibiting cytochrome c oxidase and suppressing respiration [51]. Furthermore, $\mathrm{H}_{2} \mathrm{~S}$ may protect neurons from cellular energy depletion during the stress conditions by serving as substrate to sustain ATP production $[\mathbf{5 1 , 5 6 ]}$.

Oxidative stress has been implicated in the development of many diseases including aging process and longevity [57], including the pathogenesis of Alzheimer's disease (AD) [58], Parkinson's disease (PD) [59] and other neurodegenerative diseases [60]. Physiological concentrations of $\mathrm{H}_{2} \mathrm{~S}$ gas have positive impact on protecting the neuronal cells and the supply of exogenous $\mathrm{H}_{2} \mathrm{~S}$ have shown attenuation effect on some brain diseases [61,62]. As such, the antioxidant role of $\mathrm{H}_{2} \mathrm{~S}$ is attracting substantial research attention in addition to other gaseous messenger molecules such as nitrate monoxide (NO) and carbon monoxide (CO) [51].

\section{Putative mechanism of sulfur-induced PEM}

It has been postulated that sulfite, another toxic intermediate metabolite of S, may be directly involved in the development of S-induced PEM [7], with the proposed mechanism depicted in (Figure 2). Sulfite ion is a strong nucleophile and can react with wide variety of biologically important compounds to cause toxicity [63] and the neurotoxic effects of sulfite have been increasingly recognized $[63,64]$. One electron sulfite oxidation is thought to produce sulfite radicals that have been reported to damage DNA, lipids and proteins [65]. Chiarani et al., [63] found that sulfite increased lipid peroxidation and decreased antioxidant enzyme defences in the rat brain. In 
addition, when rat and mouse neuronal cells were exposed to sulfite in vitro, there was an increase in the production of ROS and a reduction in intracellular ATP production [65]. The latter authors also found that glutamate dehydrogenase in the rat brain was inhibited by sulfites; hypothesizing that this may result in an energy deficit in the neurons, with secondary inhibition of the citric acid (TCA) cycle [65]. The destructive effects of sulfite on thiamine and its functional forms $[13,66]$ may be another mechanism to induce biochemical lesions in the brain (Figure 2).

In studies of $S$ on adverse effects of dietary $S$ in ruminants much attention has been placed on sulfide toxicity. In contrast to research in ruminants, toxic effects of sulfite have been extensively investigated in humans and laboratory animals. A toxic amount of sulfite in both the rumen and tissues due to sulfate reduction and recycling in the rumen is possible in addition to sulfide oxidation in the tissue [7]. Other known mechanisms of sulfite production include: non-enzymatic conversion from sulfide during oxidative stress [67], neutrophils produce sulfite from sulfate in response to bacterial lipopolysaccharide [68] or from 3'-phosphoadenosine 5' phosphosulfate exposure [69]. In ruminants exposed to excess dietary $S$, there is a potential for sustained generation of toxic levels of sulfite in the tissue that may contribute to the pathogenesis of S-induced malacic lesions in brain.

Possible role of sulfur-thiamine interaction in the development of malacic lesions associated with excess sulfur intake

Thiamine is present in mammalian tissues in four different forms; free-base thiamine, thiamine monophosphate (TMP), TPP, and thiamine triphosphate (TTP) [70]. Total body thiamine is the metabolic equilibrium of free-base thiamine and thiamine phosphate esters. Because the levels of total thiamine in blood or brain tissue of affected animals appear to be in the range of normal animals [35], or even elevated $[23,36]$, it is commonly believed that the pathogenesis of S-induced PEM lesions is independent of thiamine deficiency [71]. Interestingly, thiamine therapy has effectively improved the clinical status of animals affected by S-induced PEM $[11,72]$. This suggests an associated metabolic relationship between excess $\mathrm{S}$ intake and thiamine in the development of malacic lesions. An adverse effect of dietary $S$ on thiamine balance in ruminants was first reported by [73] Goetsch and Owens who observed that high dietary $\mathrm{S}$ reduced the amount of thiamine passing from the rumen in dairy steers. Increased thiamine destroying activity [74] and reduced thiamine synthesis $[\mathbf{7 4 , 7 5}$ in rumen-like conditions due to increased dietary sulfate were demonstrated in vitro. These studies suggest that excess dietary S may have detrimental effects on the host's thiamine status and are consistent with observations that feedlot cattle exposed to excess dietary $S$ have reduced blood thiamine level $[34,76]$. The importance of thiamine in the pathogenesis of S-induced PEM is further evidenced by the findings that thiamine supplementation reduced the incidence of PEM in lambs fed high dietary $S$ [12]. Furthermore, Amat et al., [11] reported that there was a potential involvement of altered thiamine metabolism in the development of S-induced PEM lesions. Elevated TPP levels in the brains of experimental heifers fed high dietary $S(0.62 \%$ $\mathrm{S}, \mathrm{DM})$ without subsequent development of brain lesions was observed. In contrast, cattle that died of S-induced PEM exhibited 36.5\% lower TPP despite 4.9-fold higher free-base thiamine in the brain tissue [11]. This suggests that excess dietary S may increase the metabolic demand for TPP in the brain where some individuals exposed to high levels of dietary $S$ may fail to generate requisite supply TPP leading to metabolic insufficiency of TPP and possibly to the development of PEM lesions.

Although the association between dietary $S$ and thiamine status can be considered as a risk factor in the pathogenesis of S-induced PEM, thiamine insufficiency cannot explain all metabolic events leading to brain lesions. Field experience with PEM indicates that administration of large doses of thiamine in early stages of S-induced PEM results in complete recovery $[1 \mathbf{1 1 8}]$, or at least in an improvement in clinical status of some animals [72], but is totally ineffective in others $[11,77]$. Paradoxically, elevated blood thiamine in lambs fed high dietary $S$ that developed PEM at the onset of clinical signs has been reported $[36,72]$. These observations indicate that, although thiamine status appears to play a central role in the pathogenesis of PEM, the vital biochemical role of this vitamin may be limited by factors affecting metabolic pathways converting thiamine to its active metabolites.

\section{Sulfur-thiamine interaction}

\section{Mechanism of sulfur-thiamine interaction}

The detrimental effects of high $\mathrm{S}$ on thiamine may result from the fact that sulfite can cleave thiamine into biologically inactive compounds sulfonic acid and thiozole [78]. The rate of thiamine cleavage is influenced by several factors including temperature, $\mathrm{pH}$, and concentrations of either thiamine or sulfite [13]. The thiamine cleavage reaction is most active at high sulfite concentration, low $\mathrm{pH}$ values, or high temperature [13]. Given the fact that there is potential to maintain a constant level of sulfite in both rumen and tissue [7], it is possible that there is sufficient concentration of sulfite that can exert an adverse effect on thiamine metabolism in the rumen and tissue.

\section{Effects of sulfur on thiamine phosphate esters and thiamine dependent enzymes}

There is a relationship between thiamine and its phosphate esters. Free-base thiamine is converted to TPP through an enzymatic phosphorylation process. Thiamine pyrophosphate is dephosphorylated to TMP and is then hydrolyzed to free-base thiamine $[\mathbf{7 9 , 8 0}$. Thiamine pyrophosphate is the metabolically active form of thiamine, being a cofactor in catalytic reaction of key enzymes: pyruvate dehydrogenase (PDH), a-ketoglutarate 
Amat et al. Veterinary Medicine and Animal Sciences 2013,

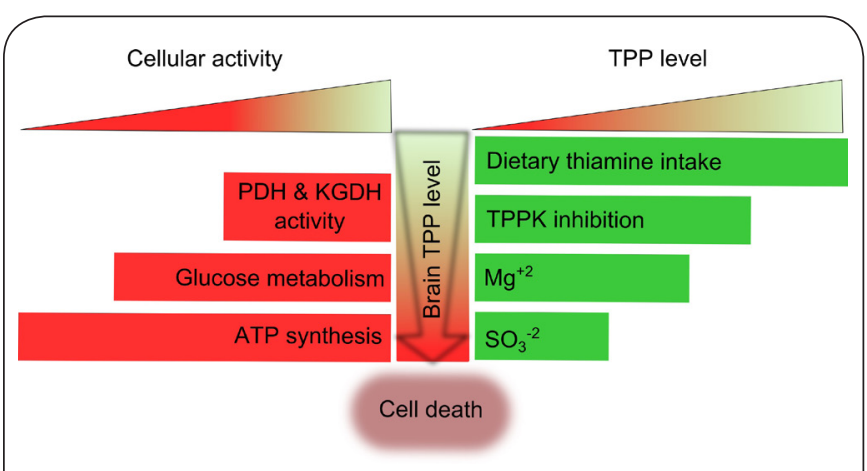

Figure 3. Correlation between TPP level and cellular activity of the brain tissue. Factors affecting TPP level are indicated in green bars. Drop of cellular activities is indicated in red bars. (ATP, adenosine triphosphate; $\mathrm{PDH}$, pyruvate dehydrogenase; $\mathrm{KGDH}$, a-ketagluterate dehydrogenase; $\mathrm{SO}_{3}^{-2}$, sulfite; TPK, thiamine pyrophosphokinase).

dehydrogenase ( $\mathrm{a}-\mathrm{KGDH}$ ) and transketolase (TK). These TPP dependent enzymes are involved in cerebral glucose and energy metabolism [81-83].

The detrimental effects of $S$ on thiamine phosphate esters have been described. Lenz and Holzer [84] reported that free-base thiamine, TMP and TPP in yeast (saccharomyces cerevisiae) were cleaved by sulfite. Sulfite could also reduce cellular TPP by inhibiting the synthesis, enhancing degradation, or both. Sulfite is reported to be involved in the degradation of TPP as it is a very active molecule [85]. In addition, sulfite is more likely to inhibit TPP synthesis from free-base thiamine by inhibiting ATP production that is required by thiamine pyrophosphokinase (TPPK). Increased degradation and reduced TPP synthesis leads to changes in the activity of thiamine dependent enzymes. Lenz and Holzer [84] reported that a-KGDH and TK were inactivated by $5 \mathrm{mM}$ sulfite in vitro within one hour to $58 \%$ and $13 \%$ of the initial values, respectively. This enzyme inactivation corresponded with a $36 \%$ reduction in the intracellular TPP. However, the detrimental effects of high dietary $S$ on thiamine dependent enzyme activity in ruminant or monogastric animals have not been investigated in details.

\section{Brain disorders associated with thiamine deficiency}

The brain is the most vulnerable organ to thiamine deficiency as it relies largely on glucose metabolism to meet its energy requirement [86]. Thiamine dependent enzymes regulate glucose metabolism. When thiamine is insufficient, brain glucose metabolism may be impaired. The inhibition of glucose metabolism in the brain results in a reduction of amino acid (AA) synthesis, diversion of AA from protein synthesis to supply energy via the TCA cycle, decreased lipid synthesis and reduced production of acetylcholine and other neurotransmitters [87].

Reduced activity of thiamine dependent enzymes is primarily caused by a decrease in TPP concentration. This has been studied experimentally in humans and amongst men with Wernicke-Korsakoff syndrome (WKS) [88]. The research conducted to evaluate the relationship between the effects of thiamine deficiency on thiamine dependent enzyme activities, and neuronal loss has been particularly focused on a-KGDH. It has been established that suppressed a-KGDH due to thiamine deficiency results in neuronal death $[\mathbf{8 8 , 8 9}$, which is not surprising as a-KGDH is a rate limiting enzyme in the TCA cycle. These metabolic consequences decreased pyruvate oxidation and increased levels of alanine and lactate in the brain [90].

Suppressed thiamine dependent enzyme activity has also been found to facilitate neuron loss in Alzheimer's disease AD [91] and Parkinson disease PD [92]. Decreased level of TPP and a dramatic reduction of TPPase activity (up to 60\%) were found in brain tissue of AD patients [93,94]. The reduced a-KGDH activity in the brains of AD patients has been observed in several studies $[95,96]$. As well, the activities of $\mathrm{PDH}[96,97]$ and TK were reduced in AD patients $[\mathbf{9 7}, \mathbf{9 8}]$.

Recent studies from our lab suggest the a-KGDH and PDH activities are decreased in the brain of S-induced PEM affected cattle (Amat et al., unpublished observation). Considering the reduced TPP in the brain tissue of S-induced PEM affected cattle, it can be postulated that thiamine dependent enzyme activity could be inhibited in the brain tissue of affected cattle. Inhibition of thiamine dependent enzyme activity would be one of the major factors leading to the neural death in PEM brains.

\section{Possible factors causing brain TPP deficiency}

Since insufficiency of TPP is a possible factor associated with a decrease in the activity of thiamine dependent enzymes, it is of importance to discuss the potential factors involved in TPP reduction in brain tissue. The causes of insufficiency of TPP in the brain might be due to: (i) thiamine deficient diet, (ii) poor absorption and transportation of thiamine, (iii) inhibition of TPP synthesis, or (iv) enhanced TPP degradation (Figure 3).

Thiamine pyrophosphate may be decreased due to the inadequate intake of thiamine. Decreased synthesis of TPP has been reported in cultured rat cerebral cells exposed to thiamine deficient media $[26,99]$. Thiamine pyrophosphate concentration in the brains of sheep fed a thiamine-free synthetic diet for 4 weeks were reduced by $22 \%$. In contrast, free-base thiamine and TMP were reduced to a minor extent relative to TPP reduction [26]. Poor absorption of thiamine from the gastrointestinal tract and the loss of liver thiamine stores due to some hepatic disease may also contribute to TPP deficiency in the brain [88].

Inhibition of TPP synthesis from free-base thiamine could be a major contributor to TPP insufficiency in the brain. Thiamine pyrophosphate is synthesised from free-base thiamine. This phosphorylation process requires adequate level of thiamine, ATP, $\mathrm{Mg}^{2+}$, as well as normal function of TPPK. The inhibition 
Amat et al. Veterinary Medicine and Animal Sciences 2013,

of TPP synthesis occurs when any one of $\mathrm{Mg}^{2+}$, ATP and freebase thiamine is insufficient or the enzyme activity of TPPK is inhibited. Mastrogiacomo et al., [100] observed that TPP was significantly reduced by $18-21 \%$ while free-base thiamine and TMP were remained unaltered in the brain of AD patients. Since ATP levels in the brains of AD patients are reduced, they proposed that this TPP reduction was due to the reduction of the TPPK activity as TPPK is an ATP dependent enzyme. Raghavendra Rao et al., [94] also reported that there was a $60 \%$ decrease in TPPK activity in the brain of an AD patient that had decreased TPP. TPP synthesis cannot be performed when there is not enough $\mathrm{Mg}^{2+}$. This may result in an apparent metabolic thiamine deficiency, even when the body has enough or excess thiamine [101].

Enhanced degradation of TPP could be another major factor that can cause insufficiency of TPP in the brain. Some factors such as nitrates and nucleophilic reagents may induce cellular TPP degradation. Since TPP is a very active molecule, it is more likely to be readily degraded by sulfite. Hydroxyl free radicals $\left(\mathrm{OH}^{-}\right)$can also degrade TPP [85]. Thiamine pyrophosphate may also be deactivated by nitrates that can react with the amino group of the pyrimidine ring of the TPP molecule [85]. It has also been shown in vitro that the $\mathrm{Cu}, \mathrm{Mo}$ and Fe could increase the degradation of TPP. Farrer [102] observed the effect of $\mathrm{Cu}$ on the rate of thiamine destruction in phosphate buffer solutions in vitro. He found that thiamine was destroyed more rapidly in the presence of $\mathrm{Cu}$ than in its absence. Farrer [102] also suggested that other metals such as Fe and Zn in phosphate nitrate solutions could accelerate thiamine degradation, but the effects of these metals on thiamine degradation have not been studied in vivo. Interestingly, we observed reduced levels of $\mathrm{Cu}$, Fe and $\mathrm{Mo}$ in the brain tissue of S-induced PEM affected steers relative to the normal cattle (Amat et al., unpublished data). Since these PEM affected steers showed also significantly reduced brain TPP in comparison to normal cattle, so it can be inferred that there may be a link between reduced $\mathrm{Cu}$, Fe and $\mathrm{Mo}$ and the reduced TPP status in PEM brains. Furthermore, the levels of a-KGDH enzyme are reduced in the brain of $A D$ patient and the reduction of these enzymes is postulated to be involved in the decomposition of TPP. The a-KGDH enzyme is acting as a "sink" to its cofactor TPP. When this protein is reduced, the affinity of TPP for its apoenzyme would be diminished; unbound TPP will thereby be easily converted or hydrolyzed to TMP by TPPase $[\mathbf{8 8 , 9 1 ]}$.

For veterinary practitioners, both thiamine deficiency and S-induced PEM should be included on a differential list when patients present with clinical signs or post-mortem findings consistent with malacic lesions. With the knowledge, cattle affected by suspected S-induced PEM may respond favourable to thiamine treatment in early disease stages; despite the conflicting evidence on its effectiveness in practice. Ensuring a balanced diet without excess $S$ is also advised. Ruminant veterinarians and other allied animal health workers are recommended to stay a breadth of advancing developments of biochemical medical advances to ensure a high quality standard of care is provided to reduce patient morbidity and mortality, in addition to improving livestock production and decreasing excess costs of treatment associated with PEM.

\section{Conclusions}

Excess $\mathrm{S}$ intake in ruminants may affect brain tissue physiology in many different ways. Sulfur metabolites sulfide and sulfite may have direct detrimental effects on brain tissue structure. More specifically, sulfite may disturb the thiamine status and metabolism systemically and in the brain tissue. Undoubtedly, these effects would have profound pathophysiological consequences in the brain. Taken together, the direct effects of S metabolites on brain tissue and diminished thiamine dependent enzymes activities will inevitably lead to neuronal death, development of malacic lesions, and eventually to fulminant PEM. Understanding the potential role of S-thiamine interaction in the development of malacic lesions is important step to determine the mechanism of S-induced PEM.

Over the last 3 decades, $\mathrm{S}$-induced PEM evolved to become a major problem in livestock industry worldwide with significant economic losses, and development of means to control this disease is urgently required. Although significant progress has been made in the understanding of $S$ toxicity pathophysiology in ruminants, more research is needed to unravel the biochemical and molecular basis of S-induced PEM.

\section{List of abbreviations}

AD: Alzheimer's disease

a-KGDH: a-ketoglutarate dehydrogenase

DM: dry mater

$\mathrm{H}_{2} \mathrm{~S}$ : hydrogen sulfide

PD: Parkinson disease

$\mathrm{PDH}$ : pyruvate dehydrogenase

PEM: polioencephalomalacia

S: sulfur

SRB: sulfate reducing bacteria

TCA: citric acid cycle

TK: transketolase

TPPK: thiamine pyrophosphokinase

TPP: thiamine pyrophosphate

TMP: thiamine monophosphate

TTP: thiamine triphosphate

WKS: Wernicke-Korsakoff syndrome

Competing interests

The authors declare that they have no competing interests.

Authors' contributions

\begin{tabular}{|l|c|c|c|c|}
\hline Authors' contributions & SA & AAO & MA & TJO \\
\hline Research concept and design & -- & -- & -- & -- \\
\hline Collection and/or assembly of data & -- & -- & -- & -- \\
\hline Data analysis and interpretation & -- & -- & -- & -- \\
\hline Writing the article & $\checkmark$ & -- & -- & -- \\
\hline Critical revision of the article & -- & $\checkmark$ & $\checkmark$ & $\checkmark$ \\
\hline Final approval of article & $\checkmark$ & $\checkmark$ & $\checkmark$ & $\checkmark$ \\
\hline Statistical analysis & -- & -- & -- & -- \\
\hline
\end{tabular}


Amat et al. Veterinary Medicine and Animal Sciences 2013,

http://www.hoajonline.com/journals/pdf/2054-3425-1-1.pdf

doi: $10.7243 / 2054-3425-1-1$

Publication history

Editor: Charles F. Rosenkrans Jr., University of Arkansas, USA.

EIC: Olivier A. E. Sparagano, Northumbria University, UK.

Received: 21-Sep-2013 Revised: 24-Oct-2013

Accepted: 06-Nov-2013 Published: 13-Nov-2013

\section{References}

1. De Sant'Ana, Fabiano JF and Barros CSL. Polioencephalomalacia in ruminants in Brazil. Braz J Vet Pathology. 2010; 3:70-9. I Pdf

2. Roberts GW and Boyd JW. Cerebrocortical necrosis in ruminants. Occurrence of thiaminase in the gut of normal and affected animals and its effect on thiamine status. J Comp Pathol. 1974; 84:365-74. | Article | PubMed

3. Niles GA, Morgan SE and Edwards WC. The relationship betweensulfur, thiamine and polioencephalomalacia - a review. Bov Pract. 2002; 36:93-9. I Pdf

4. Rachid MA, Filho EF and Carvalho AU et al. Polioencephalomalacia in cattle. Asian Journal of Animal and Veterinary Advances 2011; 6:12631. | Article

5. Gould DH. Polioencephalomalacia. J Anim Sci. 1998; 76:309-14. | Article I PubMed

6. Rammell CG and Hill JH. A review of thiamine deficiency and its diagnosis, especially in ruminants. N Z Vet J. 1986; 34:202-4. | Article | PubMed

7. Olkowski AA. Neurotoxicity and secondary metabolic problems associated with low to moderate levels of exposure to excess dietary sulphur in ruminants: a review. Vet Hum Toxicol. 1997; 39:355-60. | PubMed

8. Gould DH. Update on sulfur-related polioencephalomalacia. Vet Clin North Am Food Anim Pract. 2000; 16:481-96. | PubMed

9. Harries N. Polioencephalomalacia in feedlot cattle drinking water high in sodium sulfate. Can Vet J. 1987; 28:717.

10. Beke GJ and Hironaka R. Toxicity to beef cattle of sulfur in saline well water: a case study. Sci Total Environ. 1991; 101:281-90. | Article | PubMed

11. Amat S, McKinnon JJ, Olkowski AA, Penner GB, Simko E, Shand PJ and Hendrick $S$. Understanding the role of sulfur-thiamine interaction in the pathogenesis of sulfur-induced polioencephalomalacia in beef cattle. Res Vet Sci. 2013. I Article I PubMed

12. Rousseaux CG, Olkowski AA, Chauvet A, Gooneratne SR and Christenson DA. Ovine polioencephalomalacia associated with dietary sulphur intake. Zentralb/ Veterinarmed A. 1991; 38:229-39. | Article | PubMed

13. Leichter J and Joslyn MA. Kinetics of thiamin cleavage by sulphite. Biochem J. 1969; 113:611-5. | Pdf | PubMed Abstract | PubMed Full Text

14. Sakhaee E and Derakhshanfar A. Polioencephalomalacia associated with closantel overdosage in a goat. J S Afr Vet Assoc. 2010; 81:116-7. | Article | PubMed

15. Milad KE and Ridha GS. The occurrence of thiamine-responsive polioencephalomalacia in dromedary breeding camels in Libya:preliminary investigation of diagnosis. Iraqi Journal of Veterinary Sciences. 2009; 23119-22. I Pdf

16. Palus V, Penderis J, Jakovljevic $S$ and Cherubini GB. Thiamine deficiency in a cat: resolution of MRI abnormalities following thiamine supplementation. J Feline Med Surg. 2010; 12:807-10. | Article | PubMed

17. Brent BE and Bartley EE. Thiamin and niacin in the rumen. J Anim Sci. 1984; 59:813-22. I Article I PubMed

18. Cebra CK and Cebra ML. Altered mentation caused by polioencephalomalacia, hypernatremia, and lead poisoning. Vet Clin North Am Food Anim Pract. 2004; 20:287-302. I Article I PubMed

19. Ramos JJ, Marca C, Loste A, Garcia de Jalon JA, Fernandez A and Cubel T. Biochemical changes in apparently normal sheep from flocks affected by polioencephalomalacia. Vet Res Commun. 2003; 27:11124. | Article | PubMed

20. Ramos JJ, Ferrer LM, Garcia L, Fernandez A and Loste A. Polioencephalomalacia in adult sheep grazing pastures with prostrate pigweed. Can Vet J. 2005; 46:59-61. | PubMed Abstract | PubMed Full $\underline{\text { Text }}$

21. Murata K. Actions of two types of thiaminase on thiamin and its analogues. Ann N Y Acad Sci. 1982; 378:146-56. | Article I PubMed

22. Edwin EE and Jackman R. Thiaminase I in the development of cerebrocortical necrosis in sheep and cattle. Nature. 1970; 228:772-4. | Article | PubMed

23. Loew FM and Dunlop RH. Induction of thiamine inadequacy and polioencephalomalacia in adult sheep with amprolium. Am J Vet Res. 1972; 33:2195-205. | PubMed

24. Thornber EJ, Dunlop RH, Gawthorne JM and Huxtable CR. Polioencephalomalacia (cerebrocortical necrosis) induced by experimental thiamine deficiency in lambs. Res Vet Sci. 1979; 26:37880. I PubMed

25. Kasahara T, Ichijo S, Osame S and Sarashina T. Clinical and biochemical findings in bovine cerebrocortical necrosis produced by oral administration of amprolium. Nihon Juigaku Zasshi. 1989; 51:79-85. | Article I PubMed

26. Thornber EJ, Dunlop RH and Gawthorne JM. Thiamin deficiency in the lamb: changes in thiamin phosphate esters in the brain. J Neurochem. 1980; 35:713-7. | Article | PubMed

27. Cummings BA, Gould DH, Caldwell DR and Hamar DW. Ruminal microbial alterations associated with sulfide generation in steers with dietary sulfate-induced polioencephalomalacia. Am J Vet Res. 1995; 56:1390-5. | PubMed

28. Niles GA, Morgan SE and Edwards WC. Sulfur-induced polioencephalomalacia in stocker calves. Vet Hum Toxicol. 2000; 42:290-1. | Article | PubMed

29. Haydock D. Sulfur-induced polioencephalomalacia in a herd of rotationally grazed beef cattle. Can Vet J. 2003; 44:828-9. I PubMed Abstract | PubMed Full Text

30. Knight CW, Olson KC and Wright CL et al. Sulfur-induced polioencephalomalacia in roughage-fed feedlot steers administered high-sulfur water. West Sec Amer Soc Anim Sci. 2008; 59:364-6.

31. Cammack KM, Wright CL, Austin KJ, Johnson PS, Cockrum RR, Kessler KL and Olson KC. Effects of high-sulfur water and clinoptilolite on health and growth performance of steers fed forage-based diets. J Anim Sci. 2010; 88:1777-85. | Article | PubMed

32. Richter EL, Drewnoski ME and Hansen SL. Effects of increased dietary sulfur on beef steer mineral status, performance, and meat fatty acid composition. J Anim Sci. 2012; 90:3945-53. I Article I PubMed

33. Raisbeck MF. Is polioencephalomalacia associated with high-sulfate diets? J Am Vet Med Assoc. 1982; 180:1303-5. I Article I PubMed

34. Gooneratne SR, Olkowski AA, Klemmer RG, Kessler GA and Christensen DA. High sulfur related thiamine deficiency in cattle: A field study. Can Vet J. 1989; 30:139-46. | PubMed Abstract | PubMed Full Text

35. Gould DH, McAllister MM, Savage JC and Hamar DW. High sulfide concentrations in rumen fluid associated with nutritionally induced polioencephalomalacia in calves. Am J Vet Res. 1991; 52:1164-9. | PubMed

36. Gooneratne SR, Olkowski AA and Christensen DA. Sulfur-induced polioencephalomalacia in sheep: some biochemical changes. Can J Vet Res. 1989; 53:462-7. | PubMed Abstract | PubMed Full Text

37. Nutrient Requirements of Beef Cattle. Washington, DC: National Academy Press; 1986.

38. Low JC, Scott PR, Howie F, Lewis M, FitzSimons J and Spence JA. Sulphur-induced polioencephalomalacia in lambs. Vet Rec. 1996; 138:327-9. | Article | PubMed

39. Kul O, Karahan S, Basalan M and Kabakci N. Polioencephalomalacia in cattle: a consequence of prolonged feeding barley malt sprouts. J Vet Med A Physiol Pathol Clin Med. 2006; 53:123-8. I Article I PubMed 
40. Loneragan GH, Gould DH, Callan RJ, Sigurdson CJ and Hamar DW. Association of excess sulfur intake and an increase in hydrogen sulfide concentrations in the ruminal gas cap of recently weaned beef calves with polioencephalomalacia. J Am Vet Med Assoc. 1998; 213:1599604, 1571. | Article | PubMed

41. Dougherty RW and Cook HM. Routes of eructated gas expulsion in cattle--a quantitative study. Am J Vet Res. 1962; 23:997-1000. | PubMed

42. Powell MA and Somero GN. Hydrogen Sulfide Oxidation Is Coupled to Oxidative Phosphorylation in Mitochondria of Solemya reidi. Science. 1986; 233:563-6. | Article I PubMed

43. Ammann HM. A new look at physiologic respiratory response to $\mathrm{H}_{2} \mathrm{~S}$ poisoning. J Hazard Mater. 1986; 13:369-74. I Article

44. O'Brien $\mathrm{J}$ and Vetter RD. Production of thiosulphate during sulphide oxidation by mitochondria of the symbiont-containing bivalve Solemya reidi. J Exp Biol. 1990; 149:133-48. I Article I PubMed

45. Smith DF and Keppler DO. 2-Deoxy-D-galactose metabolism in ascites hepatoma cells results in phosphate trapping and glycolysis inhibition. Eur J Biochem. 1977; 73:83-92. | Article | PubMed

46. Gould DH, Cummings BA and Hamar DW. In vivo indicators of pathologic ruminal sulfide production in steers with diet-induced polioencephalomalacia. J Vet Diagn Invest. 1997; 9:72-6. | Article | PubMed

47. Richter EL, Drewnoski ME and Hansen SL. Effects of increased dietary sulfur on beef steer mineral status, performance, and meat fatty acid composition. J Anim Sci. 2012; 90:3945-53. I Article | PubMed

48. Neville BW, Schauer CS, Karges K, Gibson ML, Thompson MM, Kirschten LA, Dyer NW, Berg PT and Lardy GP. Effect of thiamine concentration on animal health, feedlot performance, carcass characteristics, and ruminal hydrogen sulfide concentrations in lambs fed diets based on $60 \%$ distillers dried grains plus solubles. J Anim Sci. 2010; 88:2444-55. | Article | PubMed

49. Hooser SB, Van Alstine W, Kiupel M and Sojka J. Acute pit gas (hydrogen sulfide) poisoning in confinement cattle. J Vet Diagn Invest. 2000; 12:272-5. | Article | PubMed

50. Niles GA, Morgan S, Edwards WC and Lalman D. Effects of dietary sulfur concentrations on the incidence and pathology of polioencephalomalicia in weaned beef calves. Vet Hum Toxicol. 2002; 44:70-2. | Article | PubMed

51. Guo W, Kan JT, Cheng ZY, Chen JF, Shen YQ, Xu J, Wu D and Zhu YZ. Hydrogen sulfide as an endogenous modulator in mitochondria and mitochondria dysfunction. Oxid Med Cell Longev. 2012; 2012:878052. | Article | PubMed Abstract | PubMed Full Text

52. Tan BH, Wong PT and Bian JS. Hydrogen sulfide: a novel signaling molecule in the central nervous system. Neurochem Int. 2010; 56:310. | Article | PubMed

53. Shibuya N, Koike S, Tanaka M, Ishigami-Yuasa M, Kimura Y, Ogasawara $\mathrm{Y}$, Fukui K, Nagahara N and Kimura H. A novel pathway for the production of hydrogen sulfide from D-cysteine in mammalian cells. Nat Commun. 2013; 4:1366. | Article | PubMed

54. Martelli A, Testai L, Breschi MC, Blandizzi C, Virdis A, Taddei S and Calderone V. Hydrogen sulphide: novel opportunity for drug discovery. Med Res Rev. 2012; 32:1093-130. | Article I PubMed

55. Kimura $Y$ and Kimura $H$. Hydrogen sulfide protects neurons from oxidative stress. FASEB J. 2004; 18:1165-7. I Article | PubMed

56. Fu M, Zhang W, Wu L, Yang G, Li H and Wang R. Hydrogen sulfide (H2S) metabolism in mitochondria and its regulatory role in energy production. Proc Natl Acad Sci U S A. 2012; 109:2943-8. | Article | PubMed Abstract | PubMed Full Text

57. Bonnefoy M, Drai J and Kostka T. Antioxidants to delay the process of aging: Facts and perspectives. Presse Med. 2002; 31:1174-84.

58. Butterfield DA, Perluigi M and Sultana R. Oxidative stress in Alzheimer's disease brain: new insights from redox proteomics. Eur J Pharmacol. 2006; 545:39-50. | Article | PubMed

59. Danielson SR and Andersen JK. Oxidative and nitrative protein modifications in Parkinson's disease. Free Radic Biol Med. 2008;
44:1787-94. | Article | PubMed Abstract | PubMed Full Text

60. Sayre LM, Smith MA and Perry G. Chemistry and biochemistry of oxidative stress in neurodegenerative disease. Curr Med Chem. 2001; 8:721-38. | Article | PubMed

61. Xuan A, Long D, Li J, Ji W, Zhang M, Hong L and Liu J. Hydrogen sulfide attenuates spatial memory impairment and hippocampal neuroinflammation in beta-amyloid rat model of Alzheimer's disease. J Neuroinflammation. 2012; 9:202. | Article | PubMed Abstract | PubMed Full Text

62. Lee EC, Kwan J, Leem JH, Park SG, Kim HC, Lee DH, Kim JH and Kim DH. Hydrogen sulfide intoxication with dilated cardiomyopathy. J Occup Health. 2009; 51:522-5. | Article I PubMed

63. Chiarani F, Bavaresco CS, Dutra-Filho CS, Netto CA and Wyse AT. Sulfite increases lipoperoxidation and decreases the activity of catalase in brain of rats. Metab Brain Dis. 2008; 23:123-32. | Article I PubMed

64. Reist M, Marshall KA, Jenner P and Halliwell B. Toxic effects of sulphite in combination with peroxynitrite on neuronal cells. J Neurochem. 1998; 71:2431-8. | Article | PubMed

65. Zhang $X$, Vincent AS, Halliwell $B$ and Wong KP. A mechanism of sulfite neurotoxicity: direct inhibition of glutamate dehydrogenase. J Biol Chem. 2004; 279:43035-45. | Article | PubMed

66. Zoltewicz JA, Kauffman $\mathrm{G}$ and Uray G. Nucleophilic substitution reactions of thiamin and its derivatives. ANN NEW YORK ACAD SCI. 1982; 378:7-13. | Pdf

67. Mitsuhashi H, Yamashita S, Ikeuchi H, Kuroiwa T, Kaneko Y, Hiromura $\mathrm{K}$, Ueki $\mathrm{K}$ and Nojima Y. Oxidative stress-dependent conversion of hydrogen sulfide to sulfite by activated neutrophils. Shock. 2005; 24:529-34. | PubMed

68. Mitsuhashi H, Nojima Y, Tanaka T, Ueki K, Maezawa A, Yano S and Naruse T. Sulfite is released by human neutrophils in response to stimulation with lipopolysaccharide. J Leukoc Biol. 1998; 64:595-9. I Article I PubMed

69. Mitsuhashi H, Ota F and Ikeuchi $\mathrm{K}$ et al. Sulfite is generated from PAPS by activated neutrophils. Tohoku J Exp Med. 2002; 198:125-32. I Pdf

70. Tallaksen $\mathrm{CM}$, Bell $\mathrm{H}$ and Bohmer T. Thiamin and thiamin phosphate ester deficiency assessed by high performance liquid chromatography in four clinical cases of Wernicke encephalopathy. Alcohol Clin Exp Res. 1993; 17:712-6. | Article | PubMed

71. McAllister MM, Gould DH and Hamar DW. Sulphide-induced polioencephalomalacia in lambs. J Comp Pathol. 1992; 106:267-78. | Article I PubMed

72. Olkowski AA, Gooneratne SR, Rousseaux CG and Christensen DA. Role of thiamine status in sulphur induced polioencephalomalacia in sheep. Res Vet Sci. 1992; 52:78-85. | Article I PubMed

73. Goetsch AL and Owens FN. Effects of supplement sulfate (Dynamate) and thiamin $-\mathrm{HCl}$ on passage of thiamin to the duodenum and site of digestion in steers. Arch Tierernahr. 1987; 37:1075-83. | PubMed

74. Olkowski AA, Laarveld B, Patience JF, Francis SI and Christensen DA. The effect of sulphate on thiamine-destroying activity in rumen content cultures in-vitro. Int J Vitam Nutr Res. 1993; 63:38-44. I PubMed

75. Alves de Oliveira L, Jean-Blain C, Komisarczuk-Bony S, Durix A and Durier C. Microbial thiamin metabolism in the rumen simulating fermenter (RUSITEC): the effect of acidogenic conditions, a high sulfur level and added thiamin. Br J Nutr. 1997; 78:599-613. | Article | PubMed

76. Olkowski AA, Rousseaux CG and Christensen DA. Association of sulfatewater and blood thiamine concentration in beef cattle: Field studies. Can J Anim Sc. 1991; 71:825-32. | Article

77. Bulgin MS, Lincoln SD and Mather G. Elemental sulfur toxicosis in a flock of sheep. J Am Vet Med Assoc. 1996; 208:1063-5. I PubMed

78. Williams RR, Waterman RE and Keresztesy JC et al. Studies of crystalline vitamin B. III. Cleavage of vitamin with sulfite. J. Arh. Chem. Sot. 1935; 57:536-7. I Article

79. Tallaksen $\mathrm{CM}$, Bell $\mathrm{H}$ and Bohmer $\mathrm{T}$. The concentration of thiamin and thiamin phosphate esters in patients with alcoholic liver cirrhosis. 
Amat et al. Veterinary Medicine and Animal Sciences 2013,

Alcohol Alcohol. 1992; 27:523-30. | Article | PubMed

80. Liu JY and Hurley TD. A new crystal form of mouse thiamin pyrophosphokinase. Int J Biochem Mol Biol. 2011; 2:111-8. | PubMed Abstract | PubMed Full Text

81. Lindqvist $Y$, Schneider $\mathrm{G}$ and Ermler $\mathrm{U}$ et al. Three-dimensional structure of transketolase, a thiamine diphosphate dependent

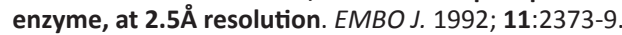

82. Bettendorff L, Mastrogiacomo F, Kish SJ and Grisar T. Thiamine, thiamine phosphates, and their metabolizing enzymes in human brain. J Neurochem. 1996; 66:250-8. | Article | PubMed

83. Widmann $M$, Radloff $R$ and Pleiss J. The Thiamine diphosphate dependent Enzyme Engineering Database: a tool for the systematic analysis of sequence and structure relations. BMC Biochem. 2010; 11:9. | Article | PubMed Abstract | PubMed Full Text

84. Lenz $\mathrm{AG}$ and Holzer $\mathrm{H}$. Cleavage of thiamine pyrophosphate by sulfite in saccharomyces cerevisiae. Z Lebensm Unters Forch. 1985; 181:41721. | Article

85. Belitz H, Grosch W and Sheiberle P. Food Chemistry. 4th Ed. SpringerVerlag Berlin Heiderberg. 2009.

86. Kevelam SH, Bugiani M, Salomons GS, Feigenbaum A, Blaser S, Prasad C, Haberle J, Baric I, Bakker IM, Postma NL, Kanhai WA, Wolf NI, Abbink TE, Waisfisz Q, Heutink $P$ and van der Knaap MS. Exome sequencing reveals mutated SLC19A3 in patients with an early-infantile, lethal encephalopathy. Brain. 2013; 136:1534-43. | Article | PubMed

87. Thomson AB, Schoeller C, Keelan M, Smith L and Clandinin MT. Lipid absorption: passing through the unstirred layers, brush-border membrane, and beyond. Can J Physiol Pharmacol. 1993; 71:531-55. | Article | PubMed

88. Butterworth RF. Thiamin deficiency and brain disorders. Nutr Res Rev. 2003; 16:277-84. | Article | PubMed

89. Butterworth RF and Heroux M. Effect of pyrithiamine treatment and subsequent thiamine rehabilitation on regional cerebral amino acids and thiamine-dependent enzymes. J Neurochem. 1989; 52:1079-84. | Article | PubMed

90. Todd $\mathrm{K}$ and Butterworth RF. Mechanisms of selective neuronal cell death due to thiamine deficiency. Ann N Y Acad Sci. 1999; 893:404-11. | Article | PubMed

91. Kish SJ, Mastrogiacomo F, Guttman M, Furukawa Y, Taanman JW, Dozic S, Pandolfo M, Lamarche J, DiStefano L and Chang LJ. Decreased brain protein levels of cytochrome oxidase subunits in Alzheimer's disease and in hereditary spinocerebellar ataxia disorders: a nonspecific change? J Neurochem. 1999; 72:700-7. | Article | PubMed

92. Mizuno $Y$, Kondo $T$ and Mori $H$. Various aspects of motor fluctuations and their management in Parkinson's disease. Neurology. 1994; 44:S29-34. | PubMed

93. Heroux M, Raghavendra Rao VL, Lavoie J, Richardson JS and Butterworth RF. Alterations of thiamine phosphorylation and of thiamine-dependent enzymes in Alzheimer's disease. Metab Brain Dis. 1996; 11:81-8. | Article | PubMed

94. Rao VL, Richardson JS and Butterworth RF. Decreased activities of thiamine diphosphatase in frontal and temporal cortex in Alzheimer's disease. Brain Res. 1993; 631:334-6. | Article | PubMed

95. Butterworth RF and Besnard AM. Thiamine-dependent enzyme changes in temporal cortex of patients with Alzheimer's disease. Metab Brain Dis. 1990; 5:179-84. | Article | PubMed

96. Casley CS, Canevari L, Land JM, Clark JB and Sharpe MA. Beta-amyloid inhibits integrated mitochondrial respiration and key enzyme activities. J Neurochem. 2002; 80:91-100. | Article | PubMed

97. Gibson GE, Sheu KF, Blass JP, Baker A, Carlson KC, Harding B and Perrino $P$. Reduced activities of thiamine-dependent enzymes in the brains and peripheral tissues of patients with Alzheimer's disease. Arch Neurol. 1988; 45:836-40. | Article | PubMed

98. Mastrogiacoma F, Lindsay JG, Bettendorff L, Rice J and Kish SJ. Brain protein and alpha-ketoglutarate dehydrogenase complex activity in Alzheimer's disease. Ann Neurol. 1996; 39:592-8. | Article | PubMed

99. Pannunzio P, Hazell AS, Pannunzio M, Rao KV and Butterworth RF.
Thiamine deficiency results in metabolic acidosis and energy failure in cerebellar granule cells: an in vitro model for the study of cell death mechanisms in Wernicke's encephalopathy. J Neurosci Res. 2000; 62:286-92. | Article | PubMed

100. Mastrogiacoma F, Bettendorff L, Grisar T and Kish SJ. Brain thiamine, its phosphate esters, and its metabolizing enzymes in Alzheimer's disease. Ann Neurol. 1996; 39:585-91. | Article | PubMed

101. Johnson $S$. The multifaceted and widespread pathology of magnesium deficiency. Med Hypotheses. 2001; 56:163-70. | Article | PubMed

102. Farrer KT. The thermal destruction of vitamin B1; the influence of the concentration of buffer salts on the rate of destruction of aneurin at 100 degrees. Biochem J. 1947; 41:167-9. | Article | PubMed

\section{Citation:}

Amat S, Olkowski AA, Atila M and O’Neill TJ. A review of polioencephalomalacia in ruminants: is the development of malacic lesions associated with excess sulfur intake independent of thiamine deficiency? Vet Med Anim Sci. 2013; 1:1.

http://dx.doi.org/10.7243/2054-3425-1-1 